\title{
Effect of Irrigation Schedules on Plant - Water Relations, Root, Grain Yield and Water Productivity of Wheat [Triticum aestivum (L.) emend. Flori \& Paol] under Various Crop Establishment Techniques
}

\author{
G.A. RAJANNA ${ }^{1 *}$, A.S. DHINDWAL ${ }^{2}$ and R.K. NANWAL ${ }^{2}$ \\ ${ }^{1}$ Division of Agronomy, IARI, PUSA Campus, New Delhi-110012, India \\ ${ }^{2}$ Department of Agronomy, CCSHAU, Hisar-125004, Haryana, India
}

(Received 5 June 2016; Accepted 14 September 2016)

Field experiment was conducted during the rabi (winter) seasons of 2012-2013 and 2013-2014, to evaluate the outcome of irrigation schedules and crop establishment techniques on physiological parameters, root parameters and water productivity of wheat (Triticum aestivum (L.) emend. Flori \& Paol) on sandy loam soils at CCS Haryana Agricultural University Hisar under four crop establishment techniques with three irrigation schedules allotted in strip plot design and replicated thrice. Zero tillage (ZT) and irrigation applied at CRI+IW:CPE $=0.90$ registered significantly highest relative water content (RWC) of wheat leaves during 2012-2013 (83.6\%) and during 2013-2014 (80.9\%) as compared to conventional tillage (CT) and minimum tillage (MT). Wheat planted on bed (FIRBS) and irrigation applied at CRI + IW: $\mathrm{CPE}=0.90$ evidenced significantly higher grain yield by $12-19 \%$ and took more days from spike initiation to anthesis, anthesis to milk stage and milk to maturity during 2012-2013 and 2013-2014 crop seasons. WUE (144.6 and $\left.155.4 \mathrm{~kg} \mathrm{ha}-\mathrm{cm}^{-1}\right)$ and IWP (4.3 and $4.5 \mathrm{~kg} \mathrm{~m}^{-3}$ ) perceived highest under bed planting by using lower total consumptive use of water $(35.71$ and $35.45 \mathrm{~cm})$ during the respective crop seasons. Thus the CU was around $6-12 \%$, lower under FIRBS as compared to other crop establishment techniques. Application of irrigation at CRI $+\mathrm{IW}: \mathrm{CPE}=0.75$ resulted in highest WUE (129.0 and $140.0 \mathrm{~kg}$ ha- $\left.\mathrm{cm}^{-1}\right)$ and IWP $\left(4.2\right.$ and $4.4 \mathrm{~kg} \mathrm{~m}^{-3}$ ) with minimum water used (37.41 and $36.22 \mathrm{~cm}$ ) during 2012-2013 and 2013-2014, respectively in contrast to other two moisture regimes.

Keywords: FIRBS, IW:CPE, phenology, productivity, semi-arid, Haryana

Abbreviations: FIRBS, furrow irrigated raised beds; CT, conventional tillage; MT, minimum tillage; ZT, zero tillage; $\mathrm{I}_{1}$, IW:CPE-0.90; $\mathrm{I}_{2}$, IW:CPE-0.75 and $\mathrm{I}_{3}$, IW:CPE-0.60; SMD, soil moisture depletion; GWC, ground water contribution; WUE, water use efficiency; IWP, irrigation water productivity; CRI, crown root initiation; IW:CPE, irrigation water: cumulative pan evaporation; CU, consumptive use; DAS, days after sowing

\footnotetext{
*Corresponding author; E-mail: rajanna.ga6@gmail.com
} 


\section{Introduction}

Wheat (Triticum aestivum (L.) emend. Flori \& Paol) is the second most important strategic cereal crop imperative for food security of India. It is principally a rabi crop of NorthWestern Plains especially in Haryana. In North-West India, it is grown in an annual sequence with rice. Although, it is grown under improved production practices the individual factor productivity has declined. Water is the scarcest input which has substantial impact on the efficiency of applied inputs and individual factor productivity particularly under semi-arid conditions. Rabi crops are irrigated by surface irrigation methods where the irrigation efficiency to be as low as $30-40 \%$ because of higher non-beneficial evapotranspiration (Rajanna et al. 2016). Scarcity and gradual decrease in the share of water for agriculture in semi-arid regions, the only option available is to produce more food per unit of available water. Surface irrigation are so complex, very difficult to implement in nature because of low performance due to poor design, operation, and maintenance (Valipour 2012; Khasraghi et al. 2015). Adding with heat stress or high temperature stress at anthesis stage has determinant effect on wheat productivity and about $40 \%$ wheat area was affected in Indo Gangetic plains (Dass et al. 2014). Under such environments, potential resource conservation techniques (RCTs) like zero tillage and FIRB planting maneuvers surface irrigation efficiency and can play a major role to save the scarce natural resources like water (Hari et al. 2010).

The bed planting wheat is one of novel techniques to save water and enhancing the productivity of other input applied. Typical irrigation savings under FIRBS ranged from 18 to $35 \%$ in wheat (Hobbs and Gupta 2003). Researchers revealed that better or equal yields under FIRBS and ZT as compared to conventional tillage. The FIRB planting systems have number of advantages like better irrigation management, better crop establishment, better weed management, less soil compaction (Karunakaran and Behera 2013) and higher N, P and K uptake (Idnani and Kumar 2013).

Efficient technologies and strategies will greatly enhance the water productivity by minimizing non-beneficial ET. Irrigation scheduling is highly location specific and several criteria have been used by researchers for scheduling irrigation in wheat to improve the water productivity. At the field level water productivity can be improved by minimizing the losses (15-40\%) during water application and distribution and proper irrigation scheduling for a particular crop is important to achieve higher application efficiency. Prihar et al. (1976) suggested climatological (IW:CPE) approach which integrates all weather parameters which is evaluated extensively to develop optimum irrigation schedules for different crops and agro-climatic regions of the country. Water supplied on IW:CPE basis was more economical and convenient than other criteria with better crop yields and water use efficiency. Production technologies such as scheduling irrigation and planting techniques leading to higher productivity per unit of water use need to be developed. Since, the behaviour of water distribution in the root zone soil and its use by the crops and thereby the irrigation schedule under different crop establishment techniques is likely to be different than the normal tillage practices and individual crops, the present investigation was conducted to find out performance of wheat in terms of growth, yield, physiology and water use under different crop establishment techniques and irrigation schedules. 


\section{Materials and Methods}

Field experiment was conducted during rabi (winter) seasons of 2012-2013 and 20132014 at Agronomy Research Farm, CCS Haryana Agricultural University Hisar situated at $29^{\circ} 10^{\prime}$ North latitude and $75^{\circ} 46^{\prime}$ East longitudes at an elevation of $215.2 \mathrm{~m}$ above mean sea level. The investigation consisted of four crop establishment techniques, viz. furrow irrigated raised bed system (FIRBS), conventional tillage (CT), minimum tillage (MT) and zero tillage (ZT) in horizontal or main plots and three irrigation schedules, viz. $\mathrm{CRI}+\mathrm{IW}: \mathrm{CPE}=0.90\left(\mathrm{I}_{1}\right), \mathrm{CRI}+\mathrm{IW}: \mathrm{CPE}=0.75\left(\mathrm{I}_{2}\right)$ and $\mathrm{CRI}+\mathrm{IW}: \mathrm{CPE}=0.60\left(\mathrm{I}_{3}\right)$ in subplots using strip plot design simultaneously with three replications. Beds of $75 \mathrm{~cm}$ each was made in such a way that three rows of wheat were planted at $15 \mathrm{~cm}$ row spacing on top of the beds (FIRBS). Under CT, two harrowing + two ploughings, under MT, one harrowing + one ploughing, under zero tillage (ZT) no tillage operations were adopted. The experiment was carried out on the same layout during both the years. The soil was sandy loam in texture having $1.42 \mathrm{~g} \mathrm{~cm}^{-3}$ bulk density, containing $0.58 \%$ organic carbon and $4.6 \mathrm{~mm} / \mathrm{h}$ infiltration rate.

The pan evaporation was 357.2 and $341.1 \mathrm{~mm}$ and the rainfall received was 113.8 and $78.6 \mathrm{~mm}$ during the crop seasons of 2012-2013 and 2013-2014, respectively. The mean weekly maximum temperature in rabi 2012-2013 ranged between 11.6 to $37.0{ }^{\circ} \mathrm{C}$ and minimum between 1.6 to $17.0^{\circ} \mathrm{C}$, while, their corresponding values in rabi 2013-2014 were 16.4 to $33.3{ }^{\circ} \mathrm{C}$ and 2.4 to $18.4{ }^{\circ} \mathrm{C}$. After a pre-sown irrigation, wheat cv ' $\mathrm{WH} 711$ ' was sown at $20 \mathrm{~cm}$ apart. While in FIRBS, three rows of wheat were adjusted at $15 \mathrm{~cm}$ apart on $45 \mathrm{~cm}$ beds. All the other cultural operations were carried out as per university recommendations. The water table was 148 and $152 \mathrm{~cm}$ deep; fluctuated around 141 and $155 \mathrm{~cm}$ during the active growth period of the crop and was 155 and $168 \mathrm{~cm}$ at harvest, during the respective two crop seasons in the experimental field. Irrigations were applied in individual plots and the depth was measured with the help of current meter based on the IW:CPE ratios during respective crop seasons. The total number of post-sown irrigations applied were 3, 2 and 2 during both the years under CRI + IW:CPE $=0.90,0.75$ and 0.60 moisture regimes, respectively.

Phenological development of the wheat crop was recorded in terms of number of days taken when $50 \%$ of the plants reached the particular phenological stage as reported by Vanderlip (1972). Root depth was measured by taking soil core samples with the help of root auger (15 cm height and $7.5 \mathrm{~cm}$ diameter). The core samples were taken up to a depth of $90 \mathrm{~cm}$ below which no live roots were found. Soil samples were put in a muslin cloth on the sieve and then washed with water and fresh roots was separated. Root density and dry weight were measured at anthesis stage where the fresh root samples separated for root depth were sun dried and then oven dried at $65^{\circ} \mathrm{C}$ till they attained constant weight. Leaf water potential ( $\Psi$ leaf) was measured from fully expanded third leaf from top between 12.00 to $14.00 \mathrm{~h}$ with the help of hand held infrared thermometer (IRT) as described by Scholander et al. (1965). Relative water content was estimated as per the method of Barrs and Weatherley (1962) at anthesis. 
The total water use (CU) was calculated by adding contribution from different sources, i.e. depletion from soil, rainfall, contribution from shallow ground water, rainfall and post-sown irrigations by wheat crop in both the years. Soil profile moisture depletion was calculated by using gravimetric method. The water use efficiency and irrigation water productivity was calculated as the production of economic yield per unit of total amount of water used or irrigation water used. During both the crop seasons economic analysis of the data was done based on the prevailing cost of inputs/operations and price of the marketable produce. The data was analysed through analysis of variance (ANOVA) technique for a strip plot design and presented at $5 \%$ level of significance $(\mathrm{P}=0.05)$.

\section{Results}

\section{Phenology of wheat}

Zero tillage (ZT) wheat took significantly more number of days to attain anthesis (91.0 and 91.4 days) than CT and milking stage (106.2 and 107.3 days) than CT and MT during 2012-13 and 2013-14 crop seasons, respectively. Planting wheat with CT took lesser days to attain the anthesis, milk and maturity stages during both the crop seasons, however no difference between CT and minimum tillage (MT) at milk stage was observed (Table $\mathrm{S} 1 *$ ). Irrigation applied at $\mathrm{I}_{3}$ took significantly less number of days to attain anthesis (89.3 and 89.5), milk stage (103.5 and 105.4) and physiological maturity (128.6 and 128.1) than at $I_{1}$ during both the seasons, respectively, but the difference between $I_{1}$ and $\mathrm{I}_{2}$ was not marked (Table S1). The treatment receiving irrigation at $\mathrm{I}_{1}$ took 130.2 and 129.3 days to mature as compared to 128.6 and 128.1 days with $\mathrm{I}_{3}$ in the respective two crop seasons.

\section{Relative water content and canopy temperature depression}

Considerably higher relative water content (RWC) at anthesis was observed with ZT during 2012-2013 (83.6\%) and during 2013-2014 (80.9\%) as compared to CT and MT. Similarly, the CTD of wheat leaves measured at anthesis stage was also higher with ZT $\left(-1.83\right.$ and $\left.-1.91{ }^{\circ} \mathrm{C}\right)$ followed by FIRBS $\left(-1.89\right.$ and $\left.-1.98{ }^{\circ} \mathrm{C}\right)$ during $2012-2013$ and 2013-2014, respectively (Table S1). The water potential of $3^{\text {rd }}$ leaf $\left(\Psi_{\text {leaf }}\right)$ from top varied under method of planting and the water supply conditions. Lowest leaf water potential at anthesis stage was recorded significantly with CT $(2.88$ and $2.54,-\mathrm{MPa})$ compared to other methods during both the crop years, respectively (Table S1). However, highest leaf water potential was recorded with ZT followed by FIRBS. Among the irrigation schedules, irrigation applied at $\mathrm{I}_{1}$ resulted in significantly higher RWC during 2012-2013 (85.3\%) and during 2013-2014 (85.0\%) as compared to lower moisture regimes. Also, significantly lowest leaf water potential was recorded under lower moisture regime of $\mathrm{I}_{3}$ (2.79 and 2.44, - MPa) during both the crop seasons, respectively. Contrastingly, irriga-

\footnotetext{
*Further details about the Electronic Supplementary Material (ESM) can be found at the end of the article.
} 
tion applied at $\mathrm{I}_{2}(\mathrm{CRI}+\mathrm{IW}: \mathrm{CPE}=0.75)$ resulted in higher $\mathrm{CTD}\left(-1.88\right.$ and $\left.-2.26{ }^{\circ} \mathrm{C}\right)$ as compared to other irrigation schedules during both the crop seasons, respectively.

\section{Wheat productivity}

Wheat planted under FIRBS produced significantly higher grain yield (5.17, 5.51 and 5.34 t ha ${ }^{-1}$ ) as compared to other crop establishment techniques during 2012-2013 and 20132014 as well as on pooled basis but the difference with ZT was not significant during 20132014 (Table S2). Application of irrigation at higher moisture regimes resulted in significantly higher grain yield and biological yields than lower moisture regimes during 20122013 and 2013-2014 but the difference between $I_{1}$ and $I_{2}$ was not substantial. On pooled basis also, irrigation schedule of $\mathrm{I}_{1}$ resulted in evidently higher grain yield and biological yields (5.12 and $11.78 \mathrm{tha}^{-1}$, respectively) as compared to other irrigation schedules.

\section{Root distribution}

Maximum root density of wheat at anthesis was observed in top 0-15 cm soil depth and declined steeply with increasing soil depth. In 0-15 cm soil depth, bed (FIRBS) planted wheat produced significantly higher root density of 53.6 and $56.8 \mathrm{~kg} \mathrm{~m}^{-3}$ during 2012 2013 and 2013-2014 seasons, respectively, compared to CT and MT but was statistically at par with ZT (Table S2). Whereas, in 15-30 cm and 30-45 cm depths, significantly higher root density was observed with $\mathrm{CT}$ as compared to other crop establishment techniques. Irrigation applied at $\mathrm{I}_{1}$ resulted in considerably higher root density in $0-15 \mathrm{~cm}$, i.e. 52.4 and $55.8 \mathrm{~kg} \mathrm{~m}^{-3}$ during 2012-2013 and 2013-2014, respectively distinguished to other irrigation schedules. However, in all other depths maximum root density was observed with lower moisture regimes. Irrigation applied at $\mathrm{I}_{3}$ resulted in significantly higher root density at $15-30 \mathrm{~cm}\left(3.53\right.$ and $\left.3.54 \mathrm{~kg} \mathrm{~m}^{-3}\right)$ and in $30-45 \mathrm{~cm}$ depths (1.56 and 1.38 $\mathrm{kg} \mathrm{m}^{-3}$ ) during the respective two crop seasons.

Roots penetrated to a significantly deeper depth under bed planted wheat compared to other tillage practices at 90 DAS (Table S2). FIRBS planted wheat recorded significantly deeper root depth of $65.6 \mathrm{~cm}$ during 2012-2013, and $66.9 \mathrm{~cm}$ during 2013-2014. The roots penetrated to a shallower depth under $\mathrm{ZT}$. Lower moisture regime of $\mathrm{I}_{3}$ noticed significantly higher root depth at 90 DAS $(63.7$ and $67.5 \mathrm{~cm})$ compared to higher moisture regimes during the two years, respectively. The root depth was found to be shallower under irrigation schedule of $\mathrm{I}_{1}(60.3$ and $61.6 \mathrm{~cm})$ during both the crop seasons, respectively. In higher moisture regimes the roots were concentrated in the upper layer and had greater horizontal development might be due better moisture availability. During 20122013, considerably higher root dry weight was observed with CT (5.31 g plant ${ }^{-1}$ ) compared to MT and ZT but was at par with FIRBS at 90 DAS (Table S2). While during 2013-2014, significantly higher root dry matter production was observed with FIRBS $\left(5.61 \mathrm{~g} \mathrm{plant}^{-1}\right)$. Irrigation applied at CRI $+\mathrm{IW}: \mathrm{CPE}=0.90\left(\mathrm{I}_{1}\right)$ produced significantly higher root dry weight (5.35 and $5.32 \mathrm{~g} \mathrm{plant}^{-1}$ ) compared to other irrigation schedules at 90 DAS during 2012-2013 and 2013-2014, respectively. 
Water use

The total consumptive water use by the wheat crop during 2012-2013 was relatively lowest under FIRBS $<\mathrm{ZT}<\mathrm{MT}<\mathrm{CT}$ and the respective values were $35.71<38.50<39.75<$ $40.75 \mathrm{~cm}$ during 2012-2013. The CU was around 6-12\%, lower under FIRBS, as differentiated to other crop establishment techniques (Fig. 1). While during 2013-2014, FIRBS observed lower CU of around 5-9\% than other tillage practices. Period wise maximum amount of water was used under high moisture regime of $I_{1}$ than $I_{3}$ and minimum water used was observed under $I_{2}$ during 2012-2013 and 2013-2014 (Fig. 1). Around 7-8\% lower total water was used under lower moisture regimes as compared to higher moisture regime of $I_{1}$.

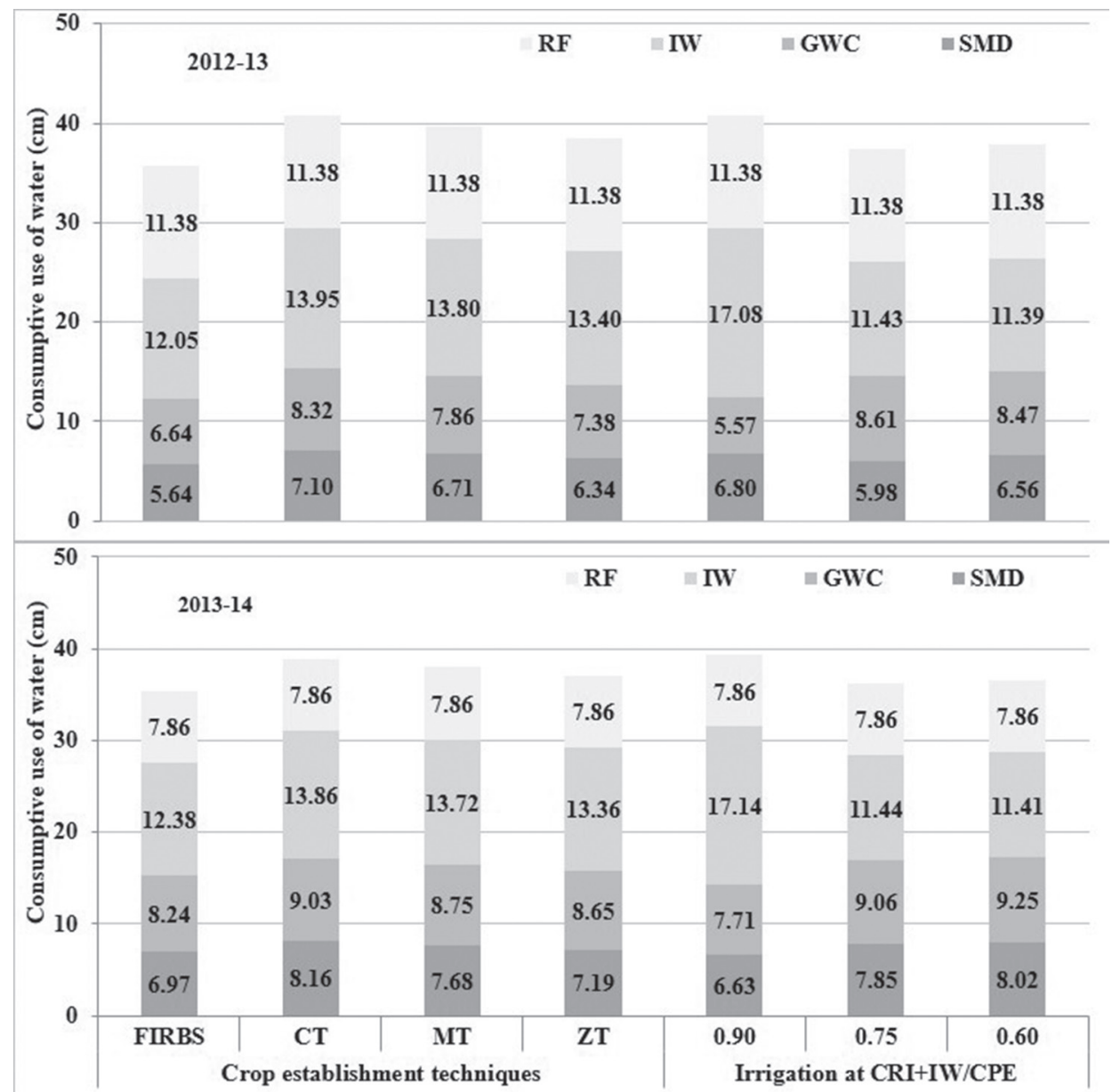

Figure 1. Components of total water use in wheat during 2012-2013 and 2013-2014 RF - Rainfall, IW - Irrigation water, GWC - Ground water contribution, SMD - Soil moisture depletion 


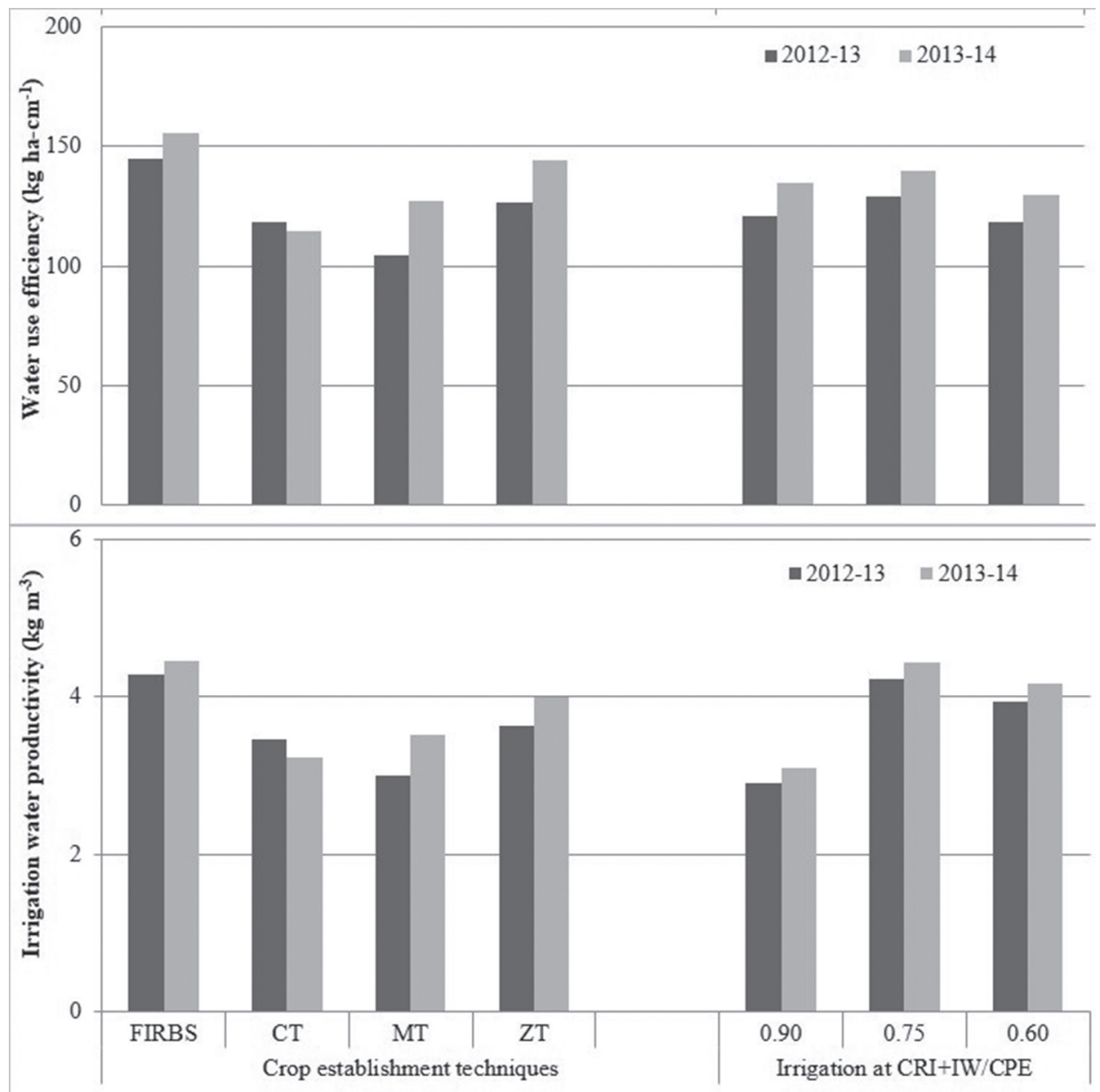

Figure 2. Water use efficiency (WUE) and irrigation water productivity (IWP) in wheat during 2012-2013 and 2013-2014

Water use efficiency and productivity

Bed (FIRBS) planted wheat perceived highest WUE (144.6 and $\left.155.4 \mathrm{~kg} \mathrm{ha-cm}^{-1}\right)$ and IWP ( 4.3 and $4.5 \mathrm{~kg} \mathrm{~m}^{-3}$ ) during both the crop seasons followed by zero tilled wheat, conventionally tilled wheat and lowest in minimum tilled (MT) wheat (Fig. 2). FIRBS (bed) planted wheat achieved highest WUE and IWP. Application of irrigation at

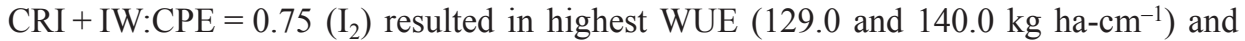
IWP (4.2 and $4.4 \mathrm{~kg} \mathrm{~m}^{-3}$ ) during 2012-2013 and 2013-2014, respectively, compared to other two moisture regimes. Though the IWP was also highest with $\mathrm{I}_{2}$, but followed by 3.9 and $4.2 \mathrm{~kg} \mathrm{~m}^{-3}$ under CRI + IW:CPE $=0.60\left(\mathrm{I}_{3}\right)$ and lowest $\left(2.9\right.$ and $\left.3.1 \mathrm{~kg} \mathrm{~m}^{-3}\right)$ with $\mathrm{CRI}+\mathrm{IW}: \mathrm{CPE}=0.90\left(\mathrm{I}_{1}\right)$ during 2012-2013 and 2013-2014, respectively. 


\section{Discussion}

\section{Phenology of wheat}

Zero tillage (ZT) wheat took significantly more number of days to attain anthesis and milking stage. Longer period (days) might be due to favourable plant growth conditions owing to better soil moisture regimes, enhanced root length/growth and temperature moderation, which facilitated better crop growth and avoid forced maturity due to terminal heat. Days taken to attain spike initiation to anthesis, anthesis to milk stage and milk to maturity were more in FIRBS during respective crop seasons (Table S1) owing to better light interception, root development and moisture availability required for enhanced plant growth. Continuous tillage operations degraded soil organic matter, which ultimately reduced soil fertility and structural stability and hence early growth under CT (Singh et al. 2013). More days taken by wheat plants under higher moisture regime of irrigation during both the crop seasons due to optimum moisture regime favoured enhanced plant growth and delayed its life cycle. No difference at early stage, i.e. spike initiation was due to the fact that irrigations applied were common under various moisture regimes. Moisture stress during vegetative or during reproductive and early irrigations in wheat caused reduction in days taken to different phenophases of the crop.

\section{Relative water content and canopy temperature depression}

RWC indicates the water status of the cells and has significant association with yield and stress tolerance (Almeselmani et al. 2006). In the present study, zero tilled wheat and FIRBS resulted in higher RWC at anthesis perhaps due to greater availability of soil moisture in respective plots (Table S1). RWC of leaf decreases with decreasing soil moisture content and results in increased leaf temperature and reduction in sink capacity which causes decreased crop growth rate and subsequently the net photosynthesis due to increase in the rate of photorespiration and thereby decline in grain yield of wheat (Chetti et al. 1997). Lowest $\Psi_{\text {leaf }}$ at anthesis stage was recorded significantly with CT in comparison with other tillage techniques could be due to lower RWC leads to more stress for water. However, highest leaf water potential was recorded with ZT followed by FIRBS due to higher RWC in the wheat leaves and lower water stress. The CTD of wheat leaves under varied tillage techniques did not influence significantly. The small variation in CTD could be that frequent rainfall and under shallow water table the plants were not water stressed to the level reflecting its effect on CTD of leaves. As water becomes limited, transpiration is reduced and which leads to increase in leaf temperature due to increased heat load on the canopy because of absorbed radiation and is positively correlated yield (Shefazadeh et al. 2012). Among the irrigation schedules, irrigation applied at $\mathrm{I}_{1}$ resulted in significantly higher RWC and higher $\Psi_{\text {leaf }}$ as compared to lower moisture regimes during both the crop seasons. Higher RWC was primarily due to sufficient moisture availability and its uptake by plants avoiding escaping water stress in leaves. Water stressed plants had reduced leaf expansion, impaired photosynthetic machinery, premature leaf 
senescence, oxidation of chloroplast lipids and changes in structure of pigments and proteins (Wajid et al. 2011).

\section{Wheat productivity}

Bed planted wheat had noticeable effect on grain yield and biological yield as compared to other crop establishment techniques (Table S2). The increase in grain yield of wheat under FIRBS could be attributed to higher yield attributes whereas; the increase in biological yield was due to higher dry matter production (data not shown). It could also attributed to better soil environment in raised beds since ponding reduces yield (Idnani and Kumar 2013) might have longer grain filling duration and higher yields (Tanwar et al. 2014). Wheat yield under FIRBS would depend on how vigorously the plants capture solar radiation falling in the gap between outer rows. Vivak et al. (2013) also obtained maximum grain and straw yield under ZT followed by CT and lower grain yield under raised bed method due to less plant population. Application of irrigation at higher moisture regimes resulted in significantly higher grain and biological yields than lower moisture regimes during 2012-2013 and 2013-2014. Higher grain and biological yields of wheat with higher moisture regimes was due to collective effect of dry matter production and yield attributes (Patil et al. 2014).

\section{Root distribution}

FIRBS had considerably higher root density during both the crop seasons at $0-15 \mathrm{~cm}$ soil depth, due to better root development under relatively better aerobic conditions in bed planted crop. The roots penetrated to deeper layers under FIRBS than others in $15-30 \mathrm{~cm}$ and 30-45 cm depths (Table S2). The root density and depth determines the soil water availability and the pattern of water extraction to a large extent (Wang et al. 2014). This increase in root depth may be attributed to catalytic effect of tillage on depth of rooting by modifying mechanical impedance; continuity, stability and size distribution of pores; air-water dynamics and thermal regime of the soil (Singh et al. 2006). Under bed planting root density was higher and dry root mass was $81.5 \%$ higher (Tanwar et al. 2014) than that of conventional tillage.

Higher root density in the upper soil depth $0-15 \mathrm{~cm}$ with $\mathrm{I}_{1}$, might be due to that the early irrigation eliminated water stress and decreased mechanical impedance, thus removing the constraints for root growth and extension into deeper layers (Singh et al. 2006). Appreciably higher root depth under lower moisture regime of $\mathrm{I}_{3}$ might be attributed to relatively deficient moisture conditions in the upper soil layer as a result of delayed irrigations in the respective plots. Due to water stress, roots invaded lower horizons and had a vertical distribution in the lower moisture regimes (Gajri et al. 1989). In higher moisture regimes the roots were concentrated in the upper layer and had greater horizontal development might be due better moisture availability. 


\section{Water use, efficiency and productivity}

The total water use by the wheat crop was around 6-12\% lower under FIRBS and the same achieved highest WUE and IWP (Figs 1 and 2). Total water use was more under CT could be due to spread of irrigation water on wider space covering more land area and the amount of irrigation water applied was higher owing to increased soil moisture depletion and use of ground water. Extreme extraction of groundwater becomes serious threat to sustainable development (Yannopoulos et al. 2015). Valipour et al. (2015) opined economically optimal water management would be possible from furrow irrigation systems with $53.4 \%$ of the simulations under kinematic wave model. The lowest consumptive use of water in FIRBS was probably because of the nature of land configuration wherein least quantity of water was applied as well as consumed (Idnani and Kumar 2013). Highest WUE and IWP under beds (Fig. 2) could be attributed to relatively higher economic yield, lower consumptive use of water and lowest irrigation water applied in the respective treatment. Tanwar et al. (2014) reported an average of $22 \%$ irrigation water saved under bed planting of wheat over conventional system. Around 7-8\% lower total water was used under lower moisture regimes as compared to higher moisture regime of $\mathrm{I}_{1}$. The main reason behind this variation in water use was due to different amount of irrigation water applied under varying moisture regimes thereby surface layers remained wet for a longer duration thereby creating the condition for higher rate of evaporation as compared to lower frequency of irrigations. Consumptive use of water by the wheat crop increased with the increase in IW:CPE ratio from 0.6 to 1.2 (Maurya and Singh 2008). Irrigation at $\mathrm{CRI}+\mathrm{IW}: \mathrm{CPE}=0.75$ noticed highest WUE and IWP (Fig. 2) were mainly because of relatively better grain yield coupled with lesser amount of irrigation water applied and also due to higher consumptive use of water under higher irrigation levels compared to lower moisture regimes which resulted in lower WUE and IWP. Higher WUE was observed with increased irrigation levels from IW:CPE ratio of 0.5 to 0.9 (Kumar and Dhindwal 2009).

The study concluded that adoption of bed planting (FIRBS) in wheat took more number of days to maturity and it leads to increase in root density, results in deeper root system and higher root dry weight. Adoption of zero tillage leads to higher relative water content as well as higher leaf water potential of wheat than conventional and minimum tillage. FIRBS (Bed) planting of wheat was found to be very successful and promising resource conservation techniques under semi-arid climatic situations. Beds had improved wheat yield by $15-19 \%$ apart from saving total water use by $9-12 \%$ through better root density, root depth and root dry weight. Among the moisture regimes, applying irrigation at $\mathrm{CRI}+\mathrm{IW}: \mathrm{CPE}=0.90$ took more number of days to attain $50 \%$ phonological stages, higher RWC and leaf water potential as well as higher grain yields. Lower moisture regime of CRI + IW:CPE $=0.75$ recorded higher WUE and IWP. 


\section{References}

Almeselmani, M., Deshmukh, P.S., Sairam, R.K., Kushwaha, S.R., Singh, T.P. 2006. Protective role of antioxidant enzymes under high temperature stress. Plant Sci. 171:382-388.

Barrs, H.D., Weatherley, P.E. 1962. A re-examination of the relative turgidity technique for estimating water deficits in leaves. Aust. J. Biol. Sci. 15:413-428.

Chetti, M.B., Hittalli, S.R., Konda, L.R., Patil, S.A. 1997. Influence of soil moisture depicts on biophysical parameters and their relationship with yield in wheat genotypes. Crop Res. 13:455-462.

Dass, A., Munda, S., Dhar, S. 2014. Irrigation methods and plant growth promoting chemicals for heat stress management in wheat. National Symp. on 'Agricultural Diversification for Sustainable Livelihood and Environmental Security’ organised by ISA, IARI New Delhi and PAU - Ludhiana during 18-20 November, 2014. PAU. Ludhiana, India. pp. 916-917.

Gajri, P.R., Prihar, S.S., Arora, V.K. 1989. Effect of N and early irrigation on root development, water use efficiency and yield of wheat on two soils. Field Crops Res. 21:103-132.

Hari, R., Kler, D.S., Singh, Y., Kumar, K. 2010. Productivity of maize (Zea mays) - wheat (Triticum aestivum) system under different tillage and crop establishment practices. Ind. J. Agron. 55:185-190.

Hobbs, P.R., Gupta, R.K. 2003. Rice-wheat cropping systems in the Indo-Gangetic Plains, issues of water productivity in relation to new resource-conserving technologies. In: Kijne, J.W., Barker, R., Molden, D. (eds), Water Productivity in Agriculture, Limits and Opportunities for Improvement. CABI. Wallingford, UK. pp. 239-253.

Idnani, L.K., Kumar, A. 2013. Performance of wheat (Triticum aestivum) under different irrigation schedules and sowing methods. Ind. J. Agric. Sci. 83:37-40.

Karunakaran, V., Behera, U.K. 2013. Effect of tillage, residue management and crop establishment techniques on energetics, water use efficiency and economics in soybean (Glycine max) - wheat (Triticum aestivum) cropping system. Ind. J. Agron. 58:42-47.

Khasraghi, M.M., Sefidkouhi, M.A.G., Valipour, M. 2015. Simulation of open- and closed-end border irrigation systems using SIRMOD. Arch. Agron. Soil Sci. 61:929-941.

Kumar, S., Dhindwal, A.S. 2009. Water productivity of wheat succeeding mungbean and sorghum in relation to planting techniques and irrigation scheduling. J. Water Manage. 17:1-7.

Maurya, R.K., Singh, G.R. 2008. Effect of crop establishment methods and irrigation schedules on economics of wheat (Triticum aestivum) production, moisture depletion pattern, consumptive use and crop water use efficiency. Ind. J. Agric. Sci. 78:830-833.

Patil, M.D., Dhindwal, A.S., Rajanna, G.A. 2014. Integrated moisture stress management in wheat. Ind. J. Agron. 59:629-633.

Prihar, S.S., Khera, K.L., Sandhu, K.S., Sandhu, B.S. 1976. Comparison of irrigation schedules based on pan evaporation and growth stages in winter wheat. Agron. J. 68:650-653.

Rajanna, G.A., Dhindwal, A.S., Sriharsha, V.P. 2016. Performance of clusterbean (Cyamopsis tetragonoloba) under variable irrigation schedules and crop-establishment techniques. Ind. J. Agron. 61:223-230.

Scholander, P.F., Hammel, H.T., Bradstrret, E.T., Hammingsen, E.A. 1965. Sap pressure in vascular plants. Science 148:139.

Shefazadeh, M.K., Mohammadi, M., Karimizadeh, R. 2012. Genotypic difference for heat tolerance traits under real field conditions. J. Food Agric. Environ. 10:484- 487.

Singh, S.S., Prasad, L.K., Upadhaya, A. 2006. Root growth, yield and economics of wheat (Triticum aestivum) as affected by irrigation and tillage practices in South Bihar. Ind. J. Agron. 51:131-134.

Singh, Y.P., Dharvendra, S., Tomar, S.S., Raj, G.K. 2013. Effect of time of pre-irrigation and tillage practices on wheat (Triticum aestivum) under pigeonpea (Cajanus cajan) - wheat cropping sequence. Ind. J. Agric. Sci. 83:1317-1321.

Tanwar, S.P.S., Rao, S.S., Regar, P.L., Shiv, D., Praveen, K., Jodha, B.S., Santra, P., Rajesh, K., Rameshwar, R. 2014. Improving water and land use efficiency of fallow - wheat system in shallow lithic calciorthid soils of arid region; Introduction of bed planting and rainy season sorghum - legume intercropping. Soil Till. Res. 138:44-55. 
Valipour, M. 2012. Comparison of surface irrigation simulation models: full hydrodynamic, zero inertia, kinematic wave. J. Agric. Sci. 4:68-74.

Valipour, M., Sefidkouhi, M.A.G., Eslamian, S. 2015. Surface irrigation simulation models: a review. Int. J. Hydro. Sci. Tech. 5:51-70.

Vanderlip, R.L. 1972. How a sorghum plant develops. Kansas State University, Co-operative. Exper. Ser. Rep. C-447. Manhattan, Kansas, USA.

Vivak, K., Yashpal, S.S., Mahesh, K.G., Arjun, S.J., Singh, S.K, Neelam, C., Jat, M.L. 2013. Effect of different tillage and seeding methods on energy use efficiency and productivity of wheat in the Indo-Gangetic Plains. Field Crops Res. 142:1-8.

Wajid, A.J., Baloch, M.J., Kumbhar, M.B., Khan, N.U., Kerio, M.I. 2011. Effect of water stress on physiological and yield parameters at anthesis stage in elite spring wheat cultivars. Sarhad J. Agric. 27:59-65.

Wang, C., Weixing, L., Qiuxia, L., Dongyun, M., Hongfang, L., Wei, F., Yingxin, X., Yunji, Z., Tiancai, G. 2014. Effects of different irrigation and nitrogen regimes on root growth and its correlation with aboveground plant parts in high-yielding wheat under field conditions. Field Crops Res. 165:138-149.

Yannopoulos, S.I., Lyberatos, G., Theodossiou, N., Li, W., Valipour, M., Tamburrino, A., Angelakis, A.N. 2015. Evolution of water lifting devices (pumps) over the centuries worldwide. A review. Water 7:5031-5060.

\section{Electronic Supplementary Material (ESM)}

Electronic Supplementary Material (ESM) associated with this article can be found at the website of CRC at http://www.akademiai.com/content/120427/

Electronic Supplementary Table S1. Influence of crop establishment techniques and irrigation scheduling on days taken to attain $50 \%$ phenological stages, relative water content, leaf water potential and canopy temperature depression (CTD) of wheat during 2012-2013 and 2013-2014

Electronic Supplementary Table S2. Root parameters, grain and biological yields of wheat under crop establishment techniques and irrigation schedules during 2012-2013 and 2013-2014 